\title{
Результаты исследований по профилактике пероноспороза лука
}

\section{И.И. Ирков, А.И. Денисенко, Н.А. Гаджикурбанов, А.Б. Полежаев}

Представлены трехлетние результаты исследований по профилактике пероноспороза лука в однолетней культуре с использованием ризосферных бактерий препаратов Экстрасол, Азотовит, Фосфатовит совместно с гуматами и фунгицидами. Установлена достоверная эффективность опытных вариантов относительно контроля при урожайности 70,0-80,0 т/га в условиях эпифитотии.

Ключевые слова: лук репчатый, грибные болезни, эпифитотия, иммунитет, ризосферные бактерии, гуматы, фунгициды.

Y рожайность лука-репки в стране по данным Госкомстата в 2017 году составила 25,4 т/га, при этом доля импорта в потреблении - 11,6\% [1].

Повышению урожайности в условиях НЧЗ препятствует распространение грибных болезней лука, особенно пероноспороза [2, 3]. Сегодня мы пока не можем обеспечить иммунитет культуры в условиях эпифитотии. Появление новых сортов и гибридов, а также средств защиты растений, дает возможность разработки эффективных мер по повышению устойчивости к болезням растений в обозначенной зоне [4].

Согласно многочисленным данным, иммунитет растений значительно усиливается применением ризосферных бактерий и гуматов [5, 6]. При этом почвенные бактерии плохо переносят солнечный свет. Применение корневых подкормок через капельный полив - наиболее эффективный вариант при защите лука от пероноспороза в настоящее время

Фирмы-производители бактериальных препаратов рекомендуют некорневое применение ризосферных бактерий совместно с гуматами [7, 8].

Таким образом, вполне логичным выглядит вариант с применением корневых и некорневых подкормок растений лука бактериальными препаратами. Однако до настоящего времени на этой культуре еще не изучены нормы и периодичность их внесения

Цель исследований - оценка эффективности применения ризосферных ассоциативных бактерий совместно с гуматами и фунгицидами для повышения устойчивости расте- ний лука репчатого к грибным болезням в однолетней культуре.

Для изучения были выбраны ризосферные бактерии препаратов Экстрасол (не менее 100 млн. КОЕ/ мл, штамм Bacillus subtilis Ч-13), Азотовит (раствор 5.109 КОЕ/г, штамм Azotobakter chroococcum), и Фосфатовит (раствор 0,12.109 $\mathrm{KOE} /\ulcorner$, штамм Bacillus mucilaginosus).

Из пестицидов для борьбы с грибными болезнями на луке [9] широко применяют медьсодержащие препараты (Косайд 2000, ВДГ; Абига-Пик, ВС; Курзат Р, СП и др.), которые зачастую малоэффективны. Достаточно хорошо зарекомендовали себя в наших опытах фунгициды, содержащие действующее вещество манкоцеб (Рапид Голд, СП; Ридомил Голд МЦ, ВДГ; Метаксил, СП и др.). В этой связи представляется целесообразным отработка при-

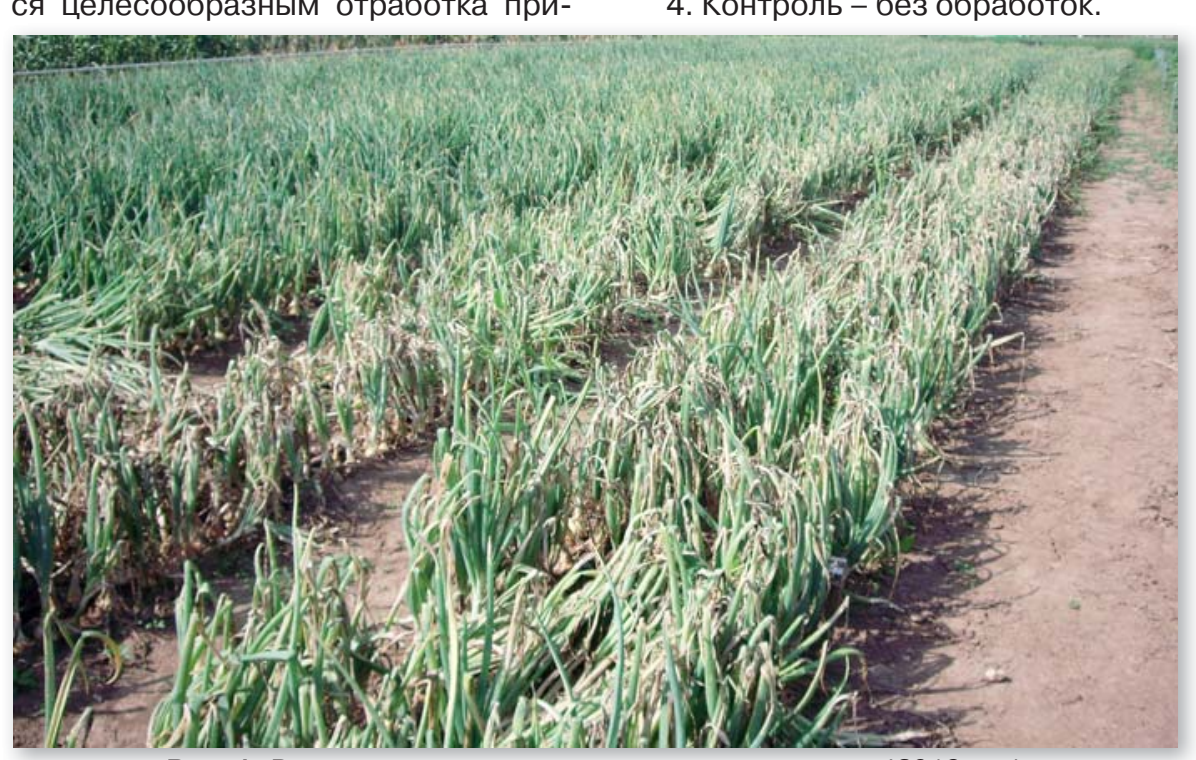

Рис. 1. Растения лука, пораженные пероноспорозом (2016 год) менения этих фунгицидов в технологическом опыте совместно с гуматами и ризосферными ассоциативными бактериями.

Для всех видов обработок нами использован натуральный гуминовый препарат из низинного торфа Росток (1\%-й раствор), который, стимулируя растение, повышает его устойчивость к грибным заболеваниям.

Во всех вариантах опытов поддерживали высокий инфекционный фон через коллекцию многолетних луков, предварительно зараженную пероноспорозом (возбудитель Peronospora destructor (Berk) Casp. (Oomycota: Peronosporaceae).

Задачи исследований корректировались в процессе исследований по годам.

\section{6 год}

В течение вегетации были выбраны следующие варианты опыта:

1. Ридомил Голд МЦ (однократная обработка) + Курзат Р, СП (двукратная обработка) + Сигнум, ВДГ (однократная обработка);

2. Вариант 1 + Азотовит 0,5 л/га + Фосфатовит 0,5 л/га (при каждой обработке фунгицидами);

3. Вариант $2+$ микроэлементы «Комплекс-1» 0,5 л/га (при каждой обработке фунгицидами);

4. Контроль - без обработок. 


\section{7 год}

В течение вегетации были выбраны следующие варианты опыта:

1. а) Азофоска $\mathrm{N}_{160} \mathrm{P}_{160} \mathrm{~K}_{160}+$ Бисолбифит (4 кг/т азофоски) + Экстрасол (20 л/га) под весеннюю фрезеровку; б) корневая подкормка: Нутрисол (100 кг/га) + Экстрасол (10 л/га); в) некорневая подкормка Экстрасол (800 л/га 1,0\%-й раствор); г) корневая подкормка $\mathrm{KNO}_{3}(100 \mathrm{kг} /$ га) + Экстрасол (10 л/га) + Азотовит (5 л/га) + Фосфатовит (5 л/га) + гуминовые кислоты (1,8 л/га 1\%-й раствор);

2. Аналогичен варианту 1 , но без Бисолбифита под фрезеровку;

3. Аналогичен варианту 1, но под фрезеровку: Азофоска $\mathrm{N}_{160} \mathrm{P}_{160} \mathrm{~K}_{160}$ + Азотовит (10 л/га) + Фосфатовит (10 л/га). Некорневая - вместо Экстрасола: Азотовит 0,5\%-й + Фосфатовит 0,5\%-й;

4. Аналогичен варианту 1, но Азофоска $\mathrm{N}_{160} \mathrm{P}_{160} \mathrm{~K}_{160}$ без бактерий под фрезеровку. Без некорневой подкормки;

5. Аналогичен варианту 1 , но без бактерий под фрезеровку;

6. Контроль. Аналогично варианту 1 , но без внесения бактериальных препаратов.

Таким образом, во всех вариантах опыта поддерживали разную степень насыщенности ризосферными ассоциативными бактериями.

В течение сезона на опытных вариантах 1-5 было проведено четыре опрыскивания согласно методики [8] препаратом Ридомил Голд МЦ, ВДГ нормой 2,5 кг/га.

\section{8 год}

В опытах 2018 года была сделана попытка выяснить роль каждого из биопрепаратов в воздействии на растения лука. Для этого были предусмотрены варианты в корневых подкормках через капельный полив:

1. Экстрасол + Азотовит + Фосфатовит $(7+7+7$ л/га) + гуминовые кислоты (1,8 л/га 1,0\%-й раствор);

2. Экстрасол (20л/га) + гуминовые кислоты (1,8 л/га 1,0\%-й раствор);

3. Азотовит + Фосфатовит $(10+10$ л/га) + гуминовые кислоты (1,8 л/га 1,0\%-й раствор);

4. Контроль - без корневых подкормок биопрепаратами.

На всех вариантах всего было проведено три корневых подкормки: начало июня, начало июля, начало августа.

Оценка эффективности применения фунгицидов: Ридомил Голд МЦ, ВДГ (Манкоцеб + Мефеноксам), Рапид Микс, СП (Манкоцеб+Металаксил). Метаксил, СП (Манкоцеб+Металаксил) - по четыре обработки нормой 2,5 кг/га с интервалом между обработками 10-14 дней, была проведена на всех фонах корневых подкормок + Экстрасол + Азотовит + Фосфатовит (1,0\%-й раствор в равных долях каждого 450 л/ га).

Контроль - шесть обработок, попарным чередованием фунгицидов без корневых подкормок биопрепаратами.

Все опыты были проведены на опытном поле ВНИИО - филиала ФГБНУ ФНЦО согласно общепринятым методикам [10] на площади $1000 \mathrm{~m}^{2}$ ежегодно. Почва участка аллювиальная луговая среднесуглинистая. Содержание гумуса в слое 0-20 см составляет 3,0-

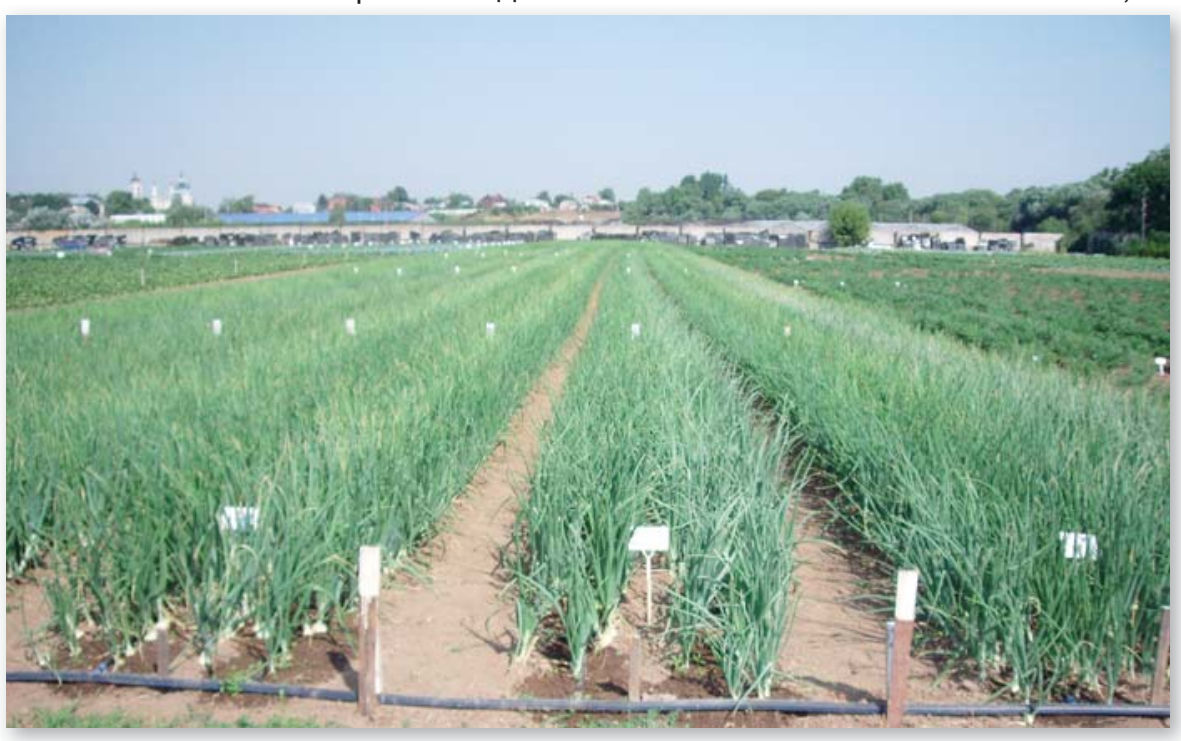

Рис. 2. Общий вид опытного участка в 2018 году
3,2\%, pH солевой вытяжки 6,0-6,2. Содержание суммы поглощенных оснований 45,0 мг-экв. на 100 г почвы в слое 0-20 см. Содержание $\mathrm{P}_{2} \mathrm{O}_{5}$ в слое 0-20 см 22,0 мг на 100 г почвы (по Чирикову), калия $-15,2$ мг (по Масловой), общего азота - 6,0 мг.

Посев - в конце апреля, по мере готовности почвы, сеялкой Gaspardo Olimpia по схеме $35+7+25+7+25+7+35$ см. Расчетная густота стояния 650-700 тыс. раст/ га.

Опыты были проведены в четырехкратной повторности. Размер учетных делянок $5 \mathrm{~m}^{2}$. Расположение делянок систематическое.

В 2016 году вегетационный период характеризовался значительным повышением среднесуточной температуры - на $2,8^{\circ} \mathrm{C}$ и снижением суммарных осадков до 312,5 мм (среднемноголетние данные 366,0 мм). В то же время во второйтретьей декаде июля и в августе имело место значительное превышение многолетних данных по осадкам: $116,7 \%$ и $207,1 \%$ соответственно. Вследствие теплой и влажной погоды произошла эпифитотия пероноспороза. Уже в конце июля лук был на 80\% поражен пероноспорозом и другими грибными заболеваниями. Вид опытного участка, пораженного пероноспорозом, на 10 августа показан на рис. 1.

Урожайность гибрида $F_{1}$ Василий (оригинатор - РГАУ-МСХА имени К.А. Тимирязева) по вариантам составила: фунгициды - 57,5 т/га; фунгициды + Азотовит + Фосфатовит 57,7 т/га; Фунгициды + Азотовит + Фосфатовит + Микроэлементы 60,7 т/га. $\mathrm{HCP}_{05}=8,9$ т/га. Таким образом, разница между вариантами несущественна.

В 2017 году начало вегетации с мая по середину июля было холодным. Так, в мае отклонение от среднемноголетних температур составило $-0,7^{\circ} \mathrm{C}$, в июне $-0,3{ }^{\circ} \mathrm{C}$, в первой декаде июля $-2,2{ }^{\circ} \mathrm{C}$. Холодная погода сопровождалась обильными осадками. За май выпало 219,2\% от среднемноголетней нормы, за июнь - 108,5\%. Полевая всхожесть опытов 2017 года составила 60$65 \%$, в то время как в предыдущем году $-80-85 \%$.

В то же время теплая погода второй половины вегетации способствовала хорошему формированию урожая. В результате учета урожайности на луке $F_{1}$ Василий получены следующие данные по вариантам, 
т/га: 1-81,0; 2-82,6; 3-85,2; 4-80,4; 5-77,8; 6 (контроль) - 45,2. При этом $\mathrm{HCP}_{05}=18,5 \mathrm{~T} /$ га.

В период вегетации на контроле первые признаки пероноспороза (остановка роста и пожелтение кончиков пера) лука зафиксированы 25-29 июля.

К 10 августа поражение растений по площади и по развитию болезни достигло 100\%. Однако средняя урожайность зафиксирована достаточно высокой - 45,2 т/га. Это свидетельствует о высоком потенциале по урожайности испытываемых сортов.

На всех вариантах опыта появления пероноспороза не зафиксировано. Следует отметить достаточно высокий коэффициент вариации по урожайности в опыте - от 8,0\% до $17,9 \%$. Это следствие изреженности всходов вследствие холодной погоды в мае - июне.

Значительное достоверное превышение урожайности над контролем зафиксировано на всех вариантах опыта. Это свидетельствует о правильном выборе направления исследований.

Наибольшая урожайность - 85,2 т/га была отмечена в третьем варианте опыта без некорневых подкормок с применением ризосферных ассоциативных бактерий в корневых подкормках на фоне гуминовых кислот. Однако разница по урожайности между всеми пятью вариантами опыта меньше $\mathrm{HCP}_{05}=18,5 \mathrm{~T} / г$ га. Вариант 4 с только корневыми подкормками не уступает всем остальным.

В 2018 году сохранился более высокий (на $4{ }^{\circ} \mathrm{C}$ за сезон) показатель среднесуточной температуры воздуха относительно многолетнего. Количество осадков составило лишь $55,8 \%$ от среднемноголетних: 204,3 мм против 360 мм. Теплый май с достаточным количеством осадков обеспечил хорошие всходы культуры. А сухой август $(42,1 \%$ осадков от многолетних данных) и начало сентября были неблагоприятны для грибных болезней, которые отсутствовали даже на контроле.

С применением капельного полива в 2018 году был получен высокий урожай лука хорошего качества. Общий вид опытного участка показан на рис. 2.

Урожайность лука $F_{1}$ Премито (оригинатор - Монсанто) по вариантам опыта составила, т/га: Экстрасол + Азотовит + Фосфатовит - 70,6; Экстрасол - 69,3; Азотовит + Фосфатовит - 69,9; только некорне- вые обработки ( $1 \%$-й раствор) - 71,3; Контроль (без бактериальных обработок) - 50,7. При этом $\mathrm{HCP}_{05}=8,7$ т/га.

Превышение опытных вариантов над контролем достоверно, а все варианты равноценны между собой. Положительный эффект от применения описанной системы препаратов значителен. Однако вопросы оптимизации и регламента обработок требуют дополнительных исследований.

Отдельно следует остановиться на выносе питательных веществ (NPK) с урожаем. По литературным данным [5, 11] вынос питательных элементов на 10 т продукции лукомрепкой колеблется: N - 28-40, Р 15-17, K - 40-46 кг, соотвественно. Приняв даже минимальное значение выноса, получаем на урожай 70,0 т/га вынос $\mathrm{N}_{196} \mathrm{P}_{105} \mathrm{~K}_{280}$. Нами в 2018 году внесено $\mathrm{N}_{194} \mathrm{P}_{160} \mathrm{~K}_{234}$, то есть коэффициент использования азота и калия больше единицы. Это подтверждает высокий уровень технологии.

Таким образом, установлено:

- профилактические обработки медьсодержащим препаратом Курзат P, СП (3 кг/га) + Азотовит 0,5 л/га + Фосфатовит 0,5 л/га в условиях эпифитотии пероноспороза неэффективны;

- корневое трехкратное внесение: Экстрасол + Азотовит + Фосфатовит $(7+7+7$ л/га) + гуминовые кислоты (1,8 л/га 1,0\%-й раствор) и четырехкратные обработки фунгицидами Ридомил Голд, Метаксил или Рапид Микс с нормой внесения 2,5 кг/га обеспечивают устойчивость лука к пероноспорозу на жестком инфекционном фоне;

- не установлено достоверной разницы по влиянию на заболеваемость и урожайность лука между корневыми (норма 20,0 л/га) и некорневыми (1,0\% раствор с нормой расхода 450 л/га) обработками микробиологическими препаратами на посевах лука;

- применение комплекса изучаемых препаратов на посевах лука позволяет обеспечить коэффициент использования удобрений по азоту и калию больше единицы;

- ввиду высокой эффективности необходимы дальнейшие исследования по регламенту применения ризосферных бактерий, гуматов и фунгицидов на луке.

Библиографический список 1.Литвинов С.С., Разин А.Ф., Шатилов М.В., Иванова
М.И. Рынок лука репчатого: состояние и основные тенденции // Экономика сельскохозяйственных и перерабатывающих предприятий. 2017. № 1. С. 58-60.

2.Ахатов А.К. и др. Болезни и вредители овощных культур и картофеля. М.: Товарищество научных изданий КМК, 2013. 463 с.

3.Купреенко Н.П. Болезни лука репчатого в Беларуси. Минск: ООО Белпринт, 2005. 119 с.

4.Ирков И.И., Берназ Н.И., Багров Р.П., Алексеева К.Л. Защита лука // Картофель и овощи. 2016. № 7. С. $14-17$

5.Литвинов С.С. Научные основы современного овощеводства. М.: Россельхозакадемия, 2008. 771 с.

6.Борисов В.А., Литвинов С.С., Романова А.В. Качество и лежкость овощей. М.: ГНУ ВНИИО, 2003. $625 \mathrm{c}$.

7.Чеботарь В.К. и др. Микробиологические препараты живых ризосферных бактерий комплексного действия группы Экстрасол (рекомендации). Спб:. Изд. ФГБНУ ВНИИСХМ, 2016. 35 с.

8.Рекомендации по применению Азотовита и Фосфатовита. М.: Изд. ООО «Промышленные инновации", 2016. С. 2

9.Справочник пестицидов и агрохимикатов, разрешенных к применению на территории Российской Федерации 2017. М.: «Издательство Агрорус», 2017. $938 \mathrm{c}$.

10.Доспехов Б.А. Методика полевого опыта. М.: Агропромиздат, 1985. $351 \mathrm{c}$

11.Борисов В.А. Система удобрения овощных культур. М.: ФГБНУ «Росинформагротех», 2016. 392 с.

\section{Об авторах}

Ирков Иван Иванович, канд. техн. наук, в.н.с. отдела технологий и инноваций, ВНИИО-филиал ФГБНУ «Федеральный научный центр овощеводства». E-mail: irkov@yandex.ru Денисенко Антон Иванович, исполнительный директор ООО «АТИ». E-mail:info@ati-agro.ru

Гаджикурбанов Назим Алимович, агроном-консультант ООО «АТИ».

E-mail: info@ati-agro.ru

Полежаев Алексей Борисович, менеджер ООО «Неопорт».

E-mail:polejaev@neoport.ru

The results of studies on the prevention of downy mildew of onions

I.I. Irkov, PhD, leading research fellow, ARRIVG-branch of FSBSI Federal Scientific Vegetable Center. E-mail: irkov@yandex.ru A.I. Denisenko, executive director "ATI» LLC. E-mail: info@ati-agro.ru

N.A. Gadzhikurbanov, agronomistconsultant «ATI» LLC.

E-mail: info@ati-agro.ru

A.B. Polezhaev, manager «Neoport» LLC. E-mail:polejaev@neoport.ru

Summary. Presented three-year results of studies on the prevention of downy mildew of onion in annual crop using rhizosphere bacteria drugs Extrasol, Azotovit, Fosfatavit together with humates and fungicides. The authentic efficiency of the experimental variants relative to the control with a yield of 70.0-80.0 t/ha in epiphytotic condition.

Keywords: onion-turnip, fungous diseases, epiphytoty, immunity, rhizosphere bacteria, humates, fungicides. 